\title{
Parental Age and Reproductive Pattern in Children with Down Syndrome
}

Lily D. Sidiarto

\begin{abstract}
Abstrak
Diteliti beberapa pola reproduktif pada orang tua dari 194 anak dengan Sindroma Down (SD) pada 2 Sekolah Pendidikan Luar Biasa (SA dan LA) dari tahun 1970 sampai 1996. Diperoleh temuan-temuan sebagai berikut: umur ibu saat melahirkan anak dengan SD terbanyak terdapat pada rentang usia 30-39 tahun (29,9\%). Nampak adanya penurunan rentang usia pada ke dua kelompok sekolah yaitu dari rentang usia 35-39 tahun (32,2\%) pada kelompok SA menjadi 30-34 tahun (30,9\%) pada kelompok LA. Usia ayah saat anak dengan SD lahir terbanyak terdapat pada rentang usia 35-39 tahun $(33,5 \%)$. Anak pertama dengan SD yang dikaitkan dengan umur ibu, kebanyakan terdapat pada rentang usia 25-29 tahun (29,3\%). Pernikahan antar-keluarga hanya terjadi pada 5 kasus (0,4\%). Tiga puluh dari $139 \mathrm{ibu}(21,6 \%)$ dari kelompok LA mengalami abortus sebelum dan/atau sesudah melahirkan anak SD dan terbanyak terdapat pada rentang usia ibu 35-39 tahun.
\end{abstract}

\begin{abstract}
A study on some reproductive pattern in parents of 194 children with Down Syndrome (DS) enrolled at 2 special schools (SA and LA) in 1970-1996 was conducted. This study revealed: most of the mothers giving birth to DS chidren were in the age range of $30-39$ years (29.9\%). There was a shift to the lower age range from 35- 39 years (32.3\%) in the SA group to 30-34 years (30.9\%) in the LA group. Most of the fathers when the DS child was born were in the age range of 35-39 years (33.5\%). Most of the first born DS children in relation to maternal age was in the age range of $25-29$ years (29.3\%). In this study we found only 5 cases (0.4\%) with consanguineous marriage. Of the 139 mothers in the LA group, 30 mothers (21.6\%) reported having miscarriages preceded and/or after the birth of the DS child.
\end{abstract}

Keywords: maternal age, paternal age, birth order, consanguineous marriage, miscarriages.

The incidence of Down Syndrome at birth varies in different countries. In 1969 Lilienfeld (cited from Smith and Berg) ${ }^{1}$ analysed 34 studies on the incidence of Down Syndrome and found that the reported rates ranged from 0.32 to 3.4 per 1000 births ( $1: 3000$ to 1:300). Hospital data from several countries showed an incidence which ranged from 1:457 to $1: 1262 .{ }^{1}$ The incidence of Down Syndrome in the Indonesian population is not yet known, but in the perinatal study (1975-1979) of the Department of Child Health, Dr. Cipto Mangunkusumo Hospital, Kadri et al in 1982 reported an incidence rate of 1.08 in 1000 live births. ${ }^{2}$ Data from the Perinatology Unit of the Department of Child Health, Dr. Cipto Mangunkusumo Hospital during the four-year period 1992-1995 showed that the incidence of DS was 1.22 in 1000 live births.

The incidence varies greatly with the maternal age at birth of a child with Down Syndrome. The relative

Department of Neurology, Faculty of Medicine, University of Indonesia/Dr. Cipto Mangunkusumo Hospital, Jakarta, Indonesia incidence data show consistency of pattern, although there are variation in the steepness of the rise of relative incidence in relation to the increase of age. Different case selection criteria used in hospital or public health surveys in other countries make it difficult to compare the data from these surveys. The incidence of Down Syndrome increases also with birth order which is correlated with the mother's age. ${ }^{1}$

The etiology of chromosomal aberations is not clear, but there are some possible causes that might be responsible to the birth of a Down syndrome infant. The known important factor to be of etiological significance for trisomy 21 is the role of maternal age. ${ }^{1,3,4,5,6}$ Reported studies mentioned also the effect of paternal age on the incidence of Down Syndrome. Other factors which are suspected as the cause of chromosomal anomalies are environmental influences such as radiation, consanguinity, sex-hormones (contraceptive use), viral infections (especially hepatitis), and thyroid autoantibodies. ${ }^{3,4,5}$

The aim of this study is to find out whether there is a difference in the distribution of the maternal and paren- 
tal age at birth of a child with Down Syndrome (DS), and the incidence of DS in relation to birth order, consanguineous marriage, or miscarriages compared with other studies. These data will be beneficial for the purpose of genetic counselling.

\section{METHODS}

Subjects for this study were children with Down Syndrome (DS) collected from 1970 to January 1996. These subjects were divided into two groups: one group were children referred to "Luhur Asih" Special Preschool for Down Syndrome Children (LA) for consultation or intervention (1983-1996), and the other group were DS school-aged children of "Sumber Asih" Special School for Mentally Retarded Children (SA).

In the LA group the diagnosis of Down Syndrome was established clinically and confirmed by cytogenetic examination which was performed at the Department of Biology, University of Indonesia or at private genetic clinics, while in the SA group the diagnosis was established clinically.

Clinical diagnosis was based on physical findings of the most characteristic signs of Down Syndrome published by Oster in 1953 and Hall in 1964 (cited from Smith and Berg), ${ }^{1}$ such as: brachycephaly /flat occiput, high-arched palate, small teeth and irregular alignment, furrowed tongue, epicanthic folds, oblique palpebral fissures, dysplastic ears, short broad hands, four-finger palmar crease, short and curved fifth finger, dysplastic middle phalanx on 5th finger, flat facial profile, muscular hypotonia, hyperextensibility or hyperflexibility. ${ }^{7,8,9,10}$ The children were diagnosed as DS when at least 6 signs were found.

In the SA and LA group information on the maternal and paternal age at birth of the children with Down Syndrome, birth order, consanguineous marriage, miscarriages and other informations were obtained by a self-administered questionaire.

\section{RESULTS}

There were 198 children with Down Syndrome and four cases were excluded because of incomplete documentation. The DS children included in this study consisted of 104 boys and 90 girls. Fifty five children ( 30 boys and 25 girls) were enrolled at "Sumber Asih" (SA) and 139 children (74 boys and 65 girls) were referral cases to "Luhur Asih" (LA).

From the LA group 117 cases were diagnosed clinically and confirmed by cytogenetic examination. In the remaining 22 cases the diagnosis was established clinically because at their home town laboratory for cytogenetic examination is not yet available or some parents refused to send their child for cytogenetic examination with the reason that their DS child is the last born child.

In clinical diagnosis, the physical findings showed that individual dysmorphism varied among these children, but at least they showed 6 or more characteristic signs of DS.

The DS children from SA were born in 1963 to 1986 , while cases from LA were born in 1980 to 1995 . The child's age when referred for consultation/intervention varied greatly from below the age of one year to 14 years (see Table 1). The youngest baby referred was 2 months old.

The distribution of the cytogenetic examination according to the new proposed cytogenetic classification of Down Syndrome ${ }^{11}$ was as follows:

One of the 117 cases $(0.85 \%)$, a boy showed normal $46, \mathrm{XY}$ karyotype. Primary or regular DS was found in 51 boys and 50 girls (totally 101 cases or $86.3 \%$ ). The secondary or Robertsonian translocation DS was found in 3 cases $(2.6 \%)$, one boy and 2 girls; the tertiary or mosaic DS in 12 cases (10.25\%), ten boys and 2 girls.

Table 1. Child's age when referred for consultation/intervention

\begin{tabular}{|c|c|c|c|}
\hline \multirow{2}{*}{$\begin{array}{l}\text { Child's age } \\
\text { (in years) }\end{array}$} & \multicolumn{2}{|c|}{ Number of cases (\%) } & \multirow{2}{*}{ Total } \\
\hline & SA & LA & \\
\hline $0-1$ & 0 & $62(44.6 \%)$ & $62(31.9 \%)$ \\
\hline $2-4$ & $6(10.9 \%)$ & $58(41.8 \%)$ & $64(33.0 \%)$ \\
\hline $5-7$ & $29(52.7 \%)$ & $17(12.2 \%)$ & $46(23.7 \%)$ \\
\hline $8-10$ & $15(27.3 \%)$ & $1(0.7 \%)$ & $16(8.3 \%)$ \\
\hline $11-14$ & $5(9.1 \%)$ & $1(0.7 \%)$ & $6(3.1 \%)$ \\
\hline Total & $55(28.4 \%)$ & $139(71.6 \%)$ & $194(100 \%)$ \\
\hline
\end{tabular}

SA = Sumber Asih group (born in 1963-1986),

$\mathrm{LA}=$ Luhur Asih group (born in 1980-1995).

In the SA group most of the children were referred for consultation in the age of 5-7 years $(52.7 \%)$ while in the LA group it was in the age of $0-1$ year $(44.6 \%)$, (Table 1).

Table 2 provides information on mother's education. The DS children in this study were all referal cases to special schools. The highest education level of most 
mothers in the SA group was senior high school $(36.4 \%)$ and in the LA group it was university level $(36.0 \%)$.

Table 2. Mother's education

\begin{tabular}{lrrr}
\hline \multirow{2}{*}{ Education } & \multicolumn{2}{c}{ Number of cases (\%) } & \multirow{2}{*}{ Total } \\
\cline { 2 - 3 } & \multicolumn{1}{c}{ SA } & \multicolumn{1}{c}{ LA } & \\
\hline Elementary & $7(12.7 \%)$ & $3(2.2 \%)$ & $10(5.2 \%)$ \\
Yunior High & $19(34.5 \%)$ & $17(12.2 \%)$ & $36(18.6 \%)$ \\
Senior High & $20(36.4 \%)$ & $43(30.9 \%)$ & $63(32.5 \%)$ \\
Academy & $5(9.1 \%)$ & $26(18.7 \%)$ & $31(15.9 \%)$ \\
University & $4(7.3 \%)$ & $50(36.0 \%)$ & $54(27.8 \%)$ \\
\hline Total & $55(28.4 \%)$ & $139(71.6 \%)$ & $194(100 \%)$ \\
\hline
\end{tabular}

$\mathrm{SA}=$ Sumber Asih group (born in 1963-1986),

LA = Luhur Asih group (born in 1980-1995).

The distribution of the maternal age at birth of the children with Down Syndrome is shown in Table 3. In the SA group most of the mothers giving birth to the DS children was in the age range of 35-39 years (median: 34 years), in the LA group it was in the age range of 30-34 years (median: 32 years) and in the overall it was in the age range of 30-39 years (median: 33 years). The number of mothers giving birth to their DS child before the age of 35 years $(54.6 \%$ in the SA group and $58.2 \%$ in the LA group) are larger than after the age of 35 years $(45.4 \%$ in the SA group and $41.8 \%$ in the LA group). Chi square analysis of the number of mothers giving birth to their DS child before and after the age of 35 years showed that there was no significant difference between the SA and LA group ( $p=0.6362)$.

Table 3. Maternal age distributions

\begin{tabular}{crrr}
\hline $\begin{array}{c}\text { Mother's age } \\
\text { (in years) }\end{array}$ & \multicolumn{2}{c}{ Number of DS cases (\%) } & \multicolumn{1}{c}{ Total } \\
\cline { 2 - 3 } & \multicolumn{1}{c}{ SA } & LA & \\
\hline-19 & $2(3.6 \%)$ & $0(0.0 \%)$ & $2(1.0 \%)$ \\
$20-24$ & $5(9.1 \%)$ & $5(3.6 \%)$ & $10(5.2 \%)$ \\
$25-29$ & $9(16.4 \%)$ & $33(23.7 \%)$ & $42(21.6 \%)$ \\
$30-34$ & $14(25.5 \%)$ & $43(30.9 \%)$ & $57(29.4 \%)$ \\
$35-39$ & $18(32.7 \%)$ & $40(28.9 \%)$ & $58(29.9 \%)$ \\
$40-44$ & $6(10.9 \%)$ & $16(11.5 \%)$ & $22(11.3 \%)$ \\
$45-49$ & $1(1.8 \%)$ & $2(1.4 \%)$ & $3(1.6 \%)$ \\
\hline Total cases & $55(28.4 \%)$ & $139(71.6 \%)$ & $194(100 \%)$ \\
\hline
\end{tabular}

$\mathrm{SA}=$ Sumber Asih group (born in 1963-1986),

LA = Luhur Asih group (born in 1980-1995).
Table 4. Paternal age distributions

\begin{tabular}{crrr}
\hline $\begin{array}{c}\text { Paternal's age } \\
\text { (in years) }\end{array}$ & \multicolumn{2}{c}{ Number of DS cases (\%) } & \multirow{2}{*}{ Total } \\
\cline { 2 - 3 } & \multicolumn{1}{c}{ SA } & \multicolumn{1}{c}{ LA } & \\
\hline-19 & $0(0.0 \%)$ & $0(0.0 \%)$ & $0(0.0 \%)$ \\
$20-24$ & $0(0.0 \%)$ & $1(0.7 \%)$ & $1(0.5 \%)$ \\
$25-29$ & $6(10.9 \%)$ & $19(13.7 \%)$ & $25(12.9 \%)$ \\
$30-34$ & $11(20.0 \%)$ & $43(30.9 \%)$ & $54(27.8 \%)$ \\
$35-39$ & $18(32.8 \%)$ & $47(33.8 \%)$ & $65(33.5 \%)$ \\
$40-44$ & $13(23.6 \%)$ & $16(11.5 \%)$ & $29(14.9 \%)$ \\
$45-49$ & $7(12.7 \%)$ & $9(6.5 \%)$ & $16(8.3 \%)$ \\
$50-54$ & $0(0.0 \%)$ & $4(2.9 \%)$ & $4(2.1 \%)$ \\
\hline Total & $55(28.4 \%)$ & $139(71.6 \%)$ & $194(100 \%)$ \\
\hline
\end{tabular}

$\mathrm{SA}=$ Sumber Asih group (born in 1963-1986),

LA = Luhur Asih group (born in 1980-1995).

Most of the fathers in both groups were in the age range of 35-39 years (Table 4).

Table 5 shows the incidence of DS in relation to birth order. Most of the DS children were first born children (28.9\% of the total cases). In the SA group the percentage was $20.0 \%$ and in the LA group it was $32.4 \%$.

Table 6 revealed the incidence of DS in first born children in relation to mother's age. In the SA group most of the first born DS cases $(27.3 \%$ ) were born to mothers in the maternal age range of 20-24 years and 30-34 years, while in the LA group the peak was in the maternal age range of $25-29$ years (44.4\%). In the total DS cases the highest percentage was in the mother's age range of $25-29$ years $(39.3 \%)$.

Table 5. The incidence of Down Syndrome in relation to birth order

\begin{tabular}{|c|c|c|c|c|}
\hline \multirow{2}{*}{$\begin{array}{l}\text { Birth } \\
\text { order }\end{array}$} & \multicolumn{3}{|c|}{ Number of cases $(\%)$} & \multirow{2}{*}{$\begin{array}{l}\text { Number of cases } \\
\text { after Penrose } \\
(1933)^{*}\end{array}$} \\
\hline & SA & LA & Total & \\
\hline 1 & $11(20.0 \%)$ & $45(32.4 \%)$ & $56(28.9 \%)$ & $21(13.6 \%)$ \\
\hline 2 & $10(18.2 \%)$ & $43(30.9 \%)$ & $53(27.3 \%)$ & $17(11.0 \%)$ \\
\hline 3 & $10(18.2 \%)$ & $24(17.3 \%)$ & 34 (17.5\%) & $16(10.4 \%)$ \\
\hline 4 & $6(10.9 \%)$ & $19(13.7 \%)$ & $25(12.9 \%)$ & $16(10.4 \%)$ \\
\hline 5 & $5(9.1 \%)$ & $3(2.2 \%)$ & $8(4.1 \%)$ & $9(5.9 \%)$ \\
\hline 6 & $3(5.5 \%)$ & $2(1.4 \%)$ & $5(2.6 \%)$ & $17(11.0 \%)$ \\
\hline 7 & $3(5.5 \%)$ & $1(0.7 \%)$ & $4(2.1 \%)$ & $15(9.7 \%)$ \\
\hline 8 & $1(1.8 \%)$ & $1(0.7 \%)$ & $2(1.0 \%)$ & $12(7.8 \%)$ \\
\hline 9 & $4(7.2 \%)$ & 0 & $4(2.1 \%)$ & $10(6.5 \%)$ \\
\hline 10 & $1(1.8 \%)$ & $1(0.7 \%)$ & $2(1.0 \%)$ & $8(5.2 \%)$ \\
\hline 11 & 0 & 0 & 0 & $4(2.6 \%)$ \\
\hline 12 & $1(1.8 \%)$ & 0 & $1(0.5 \%)$ & $2(1.3 \%)$ \\
\hline 13 & 0 & 0 & 0 & $4(2.6 \%)$ \\
\hline 14 & 0 & 0 & 0 & $2(1.3 \%)$ \\
\hline 15 & 0 & 0 & 0 & $1(0.7 \%)$ \\
\hline Total & $55(28.4 \%)$ & $139(71.6 \%)$ & $194(100 \%)$ & $154(100 \%)$ \\
\hline
\end{tabular}


Table 6. The incidence of DS in first born children in relation to mother's age

\begin{tabular}{ccrr}
\hline $\begin{array}{c}\text { Mother's age } \\
\text { (in years) }\end{array}$ & \multicolumn{2}{c}{ Number of cases (\%) } & \multicolumn{1}{c}{ Total } \\
\cline { 2 - 3 } & \multicolumn{1}{c}{ SA } & \multicolumn{1}{c}{ LA } & \\
\hline 19 & $2(18.2 \%)$ & $0(0.0 \%)$ & $2(3.6 \%)$ \\
$20-24$ & $3(27.3 \%)$ & $4(8.9 \%)$ & $7(12.5 \%)$ \\
$25-29$ & $2(18.2 \%)$ & $20(44.4 \%)$ & $22(39.3 \%)$ \\
$30-34$ & $3(27.3 \%)$ & $16(35.6 \%)$ & $19(33.9 \%)$ \\
$35-39$ & $1(9.0 \%)$ & $3(6.7 \%)$ & $4(7.1 \%)$ \\
$40-44$ & 0 & $1(2.2 \%)$ & $1(1.8 \%)$ \\
$45-49$ & 0 & $1(2.2 \%)$ & $1(1.8 \%)$ \\
\hline Total & $11(19.6 \%)$ & $45(80.4 \%)$ & $56(100 \%)$ \\
\hline
\end{tabular}

SA = Sumber Asih group (born in 1963-1986),

LA = Luhur Asih group (bom in 1980-1995).

Table 7 shows that 30 of 139 mothers $(21.6 \%)$ in the LA group had abortions before and/or after the birth of their DS child. Most mothers had miscarriages in the age group of 35-39 years. One mother in this age group had 3 miscarriages before the birth of her DS child. Two mothers in the age group of 25-29 years had 2 abortions before the birth of their DS child. One mother in the age group of 20-24 years and one mother in the age-group of 40-44 years had miscarriage before and after the birth of their first born DS child.

\section{Table 7. Miscarriages}

\begin{tabular}{cccccc}
\hline \multirow{2}{*}{$\begin{array}{c}\text { Maternal } \\
\text { age groups }\end{array}$} & \multirow{2}{*}{$\begin{array}{c}\text { No. of } \\
\text { mothers* }\end{array}$} & $\begin{array}{c}\text { No. of mothers } \\
\text { having abortion }\end{array}$ & \multicolumn{2}{c}{ No. of abortions } \\
\cline { 4 - 6 } & & & Tofore & after & \\
\hline $15-19$ & - & - & - & - & - \\
$20-24$ & 5 & 1 & 1 & 1 & 2 \\
$25-29$ & 33 & 5 & 7 & 1 & 8 \\
$30-34$ & 43 & 9 & 9 & - & 9 \\
$35-39$ & 40 & 10 & 12 & - & 12 \\
$40-44$ & 16 & 5 & 5 & 1 & 6 \\
$45-49$ & 2 & - & - & - & - \\
\hline Total & 139 & 30 & 34 & 3 & 37 \\
\hline
\end{tabular}

* The total number of mothers having a child with DS.

\section{DISCUSSION}

In the LA group the age of the children referred for consultation and early intervention shift to the younger age group compared to the SA group. As shown in
Table 1 most DS children in the LA group were referred for intervention in the age range of $0-1$ years. The youngest child referred was 2 months old. This might be related to the mother's education in which most of the mothers giving birth to their DS child in the SA group were educated at least until senior high school, while the highest percentage of mothers' education in the LA group was university level $(36.0 \%)$. The latter might be aware of the need and benefit of early intervention.

\section{Maternal age}

In this study, characteristic of the maternal age at birth to DS children in the LA group (median: 32 years) is the shift to lower age compared with the SA group (median: 34 years). Compared with a previous preliminary study in 1981 in 51 DS children, most mothers giving birth to DS children was in the age range of 35-39 years. ${ }^{12}$ Also the report of a study performed by Kadri et al in 1982 revealed that in relation to maternal age, 18 of 21 cases of Down Syndrome were born to mothers over the age of 35 years, the most being in the age group of 40-44 years. ${ }^{2}$ The difference between those studies and this study might be due to the increase of the use of family planning by mostly educated mothers recently, so that the number of DS babies born to mother over 40 years in this study was reduced.

A comparison of age distribution of mothers of children with DS in other countries is shown in Figure 1. In the Australian and British cases the minor peak was between 25 and 29 years of age and the pronounced peak between 35 and 44 years of age. In the Swedish cases the pattern was reversed, but the study was conducted in 1968-1970, compared to the Australian (1942-1957) and British (1951-1963) study; thus this reversal of pattern might be related to family planning.

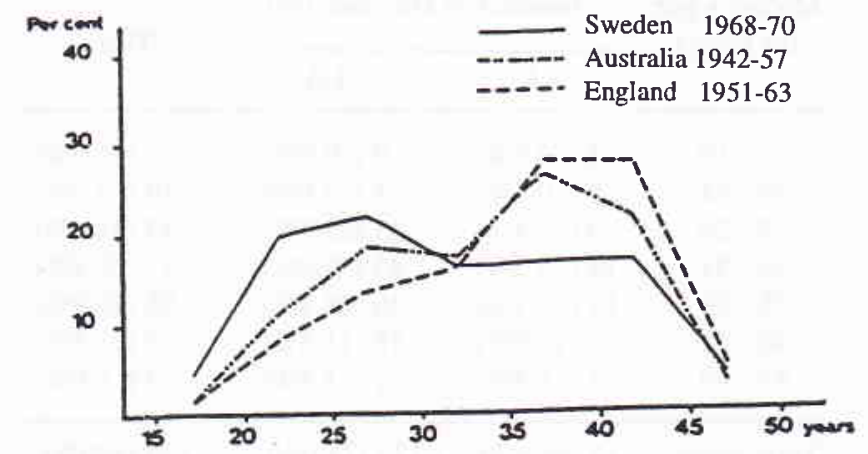

Figure 1. Age distribution of mothers of children with Down Syndrome (Linsjö, 1974) 
Factors which may be connected with Down syndrome are intrinsic and extrinsic factors. One of these factors is the disturbance in the process of cell division; the completion of the first meiotic division of the oocyte of a female depends on the hormonal control. ${ }^{1,4}$ In older women (approaches climacterium) increased risk of chromosomal aberation may be connected with less efficient hormonal control, while in teenage girls the increased risk might be connected with hormonal control which is not quite mature. Epstein mentioned that the majority of oocytes in women of 40 years and over might be aneuploid. ${ }^{5}$ In this study, $1 \%$ of the mothers giving birth to a DS child were 19 years old and $13.4 \%$ were 40 years and over.

\section{Paternal age}

Until the mid-1970s paternal age had a small effect on the incidence of Down syndrome. But with the improvement in techniques for chromosome staining and banding in recent years, a number of studies mentioned that in 20 per cent to 25 per cent of cases, the extra chromosome had come from the father. ${ }^{10}$ Epstein ${ }^{5}$ mentioned that men over 55 years of age had a significantly increased risk of having children with DS. In this study no father was over 55 years of age; the oldest were 54 years and found in 4 cases $(2.1 \%)$. Most fathers were in the age range of $35-39$ years $(33.5 \%)$, (see Table 4). Zaremba quoted the results of some studies that found no significant statistical evidence for paternal age effect independent of maternal age, and suggested that paternal age should not be treated as empirical risk values for genetic counselling. ${ }^{4}$

\section{Birth order}

Penrose observed the increasing incidence of DS in relation with increasing birth order, which is correlated with the mother's age. In this study most of the DS children were first born children $(28.9 \%$ of the total cases, $20.0 \%$ in the SA group and $32.4 \%$ in the LA group). There was a decrease in the relative incidence according to birth rank (Table 5). When correlated with mother's age, in the SA group most of the first born DS cases $(27.3 \%$ ) were in the maternal age group of 20-24 years and 30-34 years respectively, while in the LA group the peak was in the maternal age range of $25-29$ years $(44.4 \%)$. Totally the highest percentage was in the mother's age range of 25-29 years (Table 6 ). This age range is within the favourable reproductive age-range recommended by the Coordinating Body of Family Planning Programme.
Maternal age, cannot be the only factor producing Down Syndrome, because most women in this study $(57.2 \%)$ are under the age of 35 years. Benda ${ }^{7}$ found out that 41 per cent of the mothers with a DS child were at an age that was favourable for child-bearing age.

\section{Consanguineous marriage}

Studies have been carried out to obtain evidence for the participation of recessive traits in the etiology of nondisjunction and found out that there was a four fold increase in trisomy 21 in relation with consanguineous marriage. ${ }^{5}$ In this study we found only 5 cases $(0.4 \%)$ with consanguineous marriage.

\section{Miscarriages}

One of the most striking features in the case of Down Syndrome is the frequency of abortions. Benda's investigation showed that 80 of 255 mothers had reported a total of 126 miscarriages, 95 abortions preceded the birth of a DS child and 31 followed afterward. $^{7}$ In our study 30 of 139 mothers reported having abortions, 34 preceding and 3 after the birth of the DS child.

Other factors which is not included in this study are $\mathrm{x}$-rays, chemicals, viruses, and hormonal changes. Uchida et al $^{13}$ reported that a significantly greater number of children with trisomy were born after maternal radiation exposure, particularly in their late reproductive years. Zaremba ${ }^{4}$ quoted the data of Read (1982) who found that mothers of DS patients had been on contraceptive pills, and the number of DS patient mothers using contraceptive pills was higher compared to controls; more over, the use of pills increases the androgen/oestrogen index. Lindsjo ${ }^{3}$ mentioned Carr's report on the increased frequency of triploidy among abortions in mothers who had ceased to take oral contraceptives less than 6 months before conceptions. However, the data concerning the role of oral contraceptive pills should be treated with caution and need to be confirmed by other studies.

Other factor such as endocrine disturbances in the mother have not found sufficient attention. Benda ${ }^{7}$ found out that in the younger age group between 21 and $40,38.5 \%$ of mothers of a DS child showed evidence of having thyroid disorder in their history, but in the older age group between 41 and 52 only 0.8 per cent showed evidence of thyroid disorder. Higher titres of circulating thyroid antibodies in mothers of a DS child have also been reported by other studies. ${ }^{3}$ 
Prenatal detection by amniocentesis for women over the age of 35 years could be done, but in case of abnormal chromosome findings, termination of pregnancy raises legal, moral and ethical problems in Indonesia. Therefore, studies on probable risk factors in relation with DS should be suggested for preventive values.

\section{CONCLUSION}

1. Most of the mothers of a DS child were in the age range of 30-39 years; 35-39 years in the SA group (born in 1963-86) and 30-34 years in the LA group (born in 1980-95)

2. Most of the fathers of a DS child were in the age range of 35-39 years.

3. Most of the first born. DS children were born to mothers in the age group of 25-29 years.

\section{REFERENCES}

1. Smith GF, Berg JM. Down's Anomaly. 2nd edition. Edinburgh London: Churchill Livingstone, 1976.

2. Kadri N, Siregar SP, Surachman, Monintja HE. Umur ibu sebagai faktor risiko kelainan bayi Mongoloid di Rumah Sakit Dr. Cipto Mangunkusumo Jakarta, 1975-1979. Maj Obstet Ginek Indon 1982;8:147-54.

3. Lindsjö A. Down's Syndrome in Sweden. Acta Paediatr Scand 1974:63:571-76.
4. Zaremba J. Recent Medical Research. In: Lane D, StratfordB, editors. Current Approaches to Down's Syndrome. London: Cassell, 1985:27-51.

5. Epstein CJ. Down Syndrome. In: Scriver CR, Beaudet AL, Sly WS, Valle D, editors. Metabolic Basis of Inherited Disease. 6th edition. New York: MacGraw-Hill, 1989:291320.

6. Selikowitz M. Down Syndrome. The Facts. Oxford: Oxford University Press, 1990.

7. Benda CC. Down's Syndrome: Mongolism and Its Management. Revised edition. London, New York: Grune \& Stratton, 1969.

8. Smith DW. Recognizable Patterns of Human Malformation, Genetic, Embryonic, and Clinical Aspects. Philadelphia: Saunders, 1970.

9. Smith DW, Wilson AA. The Child with Down's Syndrome (Mongolism), Causes, Characteristics and Acceptance. Philadelphia: Saunders, 1973.

10. Cunningham C. Down's Syndrome: An Introduction for Parents. 2nd edition. London: A Condor Book, Souvenir Press, 1987.

11. Ramelan W. Down Syndrome: Report of a Cytogenetic Study and a New Proposed Practical Classification. Med J Indones, 1995, 4 (2):78-83.

12. Sidiarto L. The Maternal Age at Birth of Children with Down's Syndrome. In: Kenneth Bayes, Chan WMH, Ng WM, Tang FC, editors. Developing Resources for Mentally Retarded Persons. Proceedings of the 5th Asian Conference on Mental Retardation. 1981 September; Hong Kong. Hong Kong: Double Print and Art, 1982:71-3.

13. Uchida AU, Holunga R, Lawler C. Maternal Radiation and Chromosomal Aberrations. The Lancet 1968; 1045-9. 